\title{
Genome-wide identification of whole ATP-binding cassette $(A B C)$ transporters in the intertidal copepod Tigriopus japonicus
}

\author{
Chang-Bum Jeong ${ }^{1}$, Bo-Mi Kim² ${ }^{2}$ Jae-Seong Lee ${ }^{2^{*}}$ and Jae-Sung Rhee (3* $^{3^{*}}$
}

\begin{abstract}
Backgrounds: The ATP-binding cassette $(A B C)$ transporter superfamily is one of the largest transporter gene families and is observed in all animal taxa. Although a large set of transcriptomic data was recently assembled for several species of crustaceans, identification and annotation of the large $A B C$ transporter gene family have been very challenging.

Results: In the intertidal copepod Tigriopus japonicus, 46 putative ABC transporters were identified using in silico analysis, and their full-length CDNA sequences were characterized. Phylogenetic analysis revealed that the $46 \mathrm{~T}$. japonicus $A B C$ transporters are classified into eight subfamilies $(A-H)$ that include all the members of all $A B C$ subfamilies, consisting of five $A B C A$, five $A B C B$, $17 A B C C$, three $A B C D$, one $A B C E$, three $A B C F$, seven $A B C G$, and five $A B C H$ subfamilies. Of them, unique isotypic expansion of two clades of $A B C C 1$ proteins was observed. Real-time RT-PCR-based heatmap analysis revealed that most T. japonicus ABC genes showed temporal transcriptional expression during copepod development. The overall transcriptional profile demonstrated that half of all $T$. japonicus $A B C$ genes were strongly associated with at least one developmental stage. Of them, transcripts TJ-ABCH_88708 and TJ-ABCE1 were highly expressed during all developmental stages.
\end{abstract}

Conclusions: The whole set of $T$. japonicus $A B C$ genes and their phylogenetic relationships will provide a better understanding of the comparative evolution of essential gene family resources in arthropods, including the crustacean copepods.

Keywords: ATP-binding cassette transporter, Copepod, Tigriopus japonicus, Genome, Development

\section{Background}

The ATP-binding cassette $(\mathrm{ABC})$ transporters constitute one of the largest families of ubiquitous membrane proteins [1]. These proteins are present in all organisms from prokaryotes to eukaryotes (e.g., plants, fungi, yeast, and animals) and use ATP hydrolysis to transport diverse substrates (e.g., amino acids, peptides, vitamins, sugars, lipids, sterols, hormones, endogenous metabolites, inorganic anions, drugs, and metal ions) in and out of cells across biological membranes [2]. ABC transporters share highly conserved structural domains known as nucleotide binding

\footnotetext{
*Correspondence: jslee2@skku.edu; jsrhee@incheon.ac.kr

${ }^{2}$ Department of Biological Sciences, College of Science, Sungkyunkwan University, Suwon 440-746, South Korea

${ }^{3}$ Department of Marine Science, College of Natural Sciences, Incheon National University, Incheon 406-772, South Korea

Full list of author information is available at the end of the article
}

domains (NBDs, also referred to as ATP-binding cassettes) and are classified according to the presence of three sequence motifs: Walker A, Walker B, and Walker C [3]. Substrate specificity depends on the transmembrane domains (TMDs), while the ability to bind and hydrolyze ATP is achieved by the NBDs, which are related to energy production for substrate translocation or non-transport processes in a cell. These domains form either homo- or heterodimers (half transporters: one TMD and one NBD, full transporter: two TMDs and two NBDs), and they are located on a single polypeptide chain. Within the NBDs, several architectural motifs, such as the Walker motifs and $\mathrm{ABC}$ signature, can be used as unique characteristics for investigating $\mathrm{ABC}$ transporters [4].

To date, several $A B C$ transporter superfamilies have been characterized from diverse animal taxa, and there are ongoing investigations into the potential roles of each 
subfamily. Previously, 71 discrete ABC transporters were identified in the genome of the bacterium Escherichia coli strain K-12 [5], while the human genome contains only 48 ABC transporters in seven subfamilies (designated A-G) [1]. Interestingly, the eighth subfamily $\mathrm{H}$ was first identified in the Drosophila melanogaster genome [1] and has been subsequently identified in several lower taxa such as Caenorhabditis elegans [6], Daphnia pulex [7], Anopheles gambiae [8,9], Apis mellifera [9,10], Bombyx mori [9], Tetranychus urticae [11], and Tribilium castaneum [12]. However, while one member of the H subfamily has been found in the zebrafish Danio rerio [13], there is currently no evidence of the $\mathrm{H}$ subfamily in mammals. In fact, the role of $\mathrm{ABC}$ transporters is not restricted to ATP-dependent active transport as several subfamily members function as receptors or ion channels. For example, the members of the $\mathrm{E}$ and $\mathrm{F}$ subfamilies are not transporters, as they possess two NBDs, but lack TMDs. Thus, the suggested roles of both subfamilies include transcription, translation, or ribosome assembly $[14,15]$.

In invertebrates, the importance of $\mathrm{ABC}$ transporters has been emphasized due to their potential roles in a wide range of molecular and biochemical metabolisms. Regardless of genomic technology, the study of invertebrate $\mathrm{ABC}$ transporters has mainly focused on the identification and functional characterization of P-glycoprotein (P-gp) and other $A B C$ genes that are potentially involved in multidrug resistance and/or xenobiotic elimination. During the last decade, genomic analysis has significantly aided our understanding of the diversity and functions of invertebrate $\mathrm{ABC}$ superfamilies. Moreover, recent stateof-the-art sequencing technologies have provided unique opportunities for comparative analysis of the entire ABC superfamily and allowed easy access to the differentially expressed profiles in a species. Previously, Dean et al. [1] identified $56 \mathrm{ABC}$ transporters in the D. melanogaster genome and compared them to those of human ABC transporters. Sheps et al. [6] reported 60 C. elegans $\mathrm{ABC}$ transporters and suggested gene duplication and loss events in the C. elegans genome based on orthologous gene comparison from analogous genes. In the water flea D. pulex, Sturm et al. [7] suggested that 64 Daphnia ABC transporters most closely resembled those of D. melanogaster based on phylogenetic relationship. In insects, Liu et al. [9] identified $51 \mathrm{ABC}$ transporters in the silkworm B. mori and showed their spatial transcriptional expressions in multiple larval tissues. Broehan et al. [13] annotated $73 \mathrm{ABC}$ transporters in the genome of the flour beetle $T$. castaneum that have several physiological functions in developmental stages. Recently, Dermauw et al. [11] investigated $103 \mathrm{ABC}$ transporters in the genome of the polyphagous spider mite $T$. urticae, which has the largest number of $\mathrm{ABC}$ subfamilies among metazoan species. However, only a few $\mathrm{ABC}$ proteins have been functionally characterized in other invertebrates, including copepods.

Copepods are widely distributed and ecologically important invertebrates in aquatic ecosystems. T. japonicus has been identified as a significant copepod species for assessing impacts of environmental changes [16]. In the whole genome and RNA-Seq databases of $T$. japonicus [17], we identified multiple $A B C$ transporters exhibiting high similarities with those of other invertebrates. Thus, we were able to characterize all of the $\mathrm{ABC}$ transporters in T. japonicus. Although there is limited information on copepod $A B C$ gene repositories, Tribble et al. [18] initially showed P-gp-mediated tolerance of parasitic sea lice (Lepeophtheirus salmonis) against antibiotic treatment from commercial sea cage salmon farms. However, extensive $A B C$ gene mining and functional characterization have not yet been reported in copepods. In this study, we identified and characterized 46 putative $T$. japonicus $\mathrm{ABC}$ transporters at the genome- and transcriptome levels. In addition, we investigated their temporal transcriptional levels using real-time RT-PCR-based heatmap analysis for different developmental stages.

\section{Results and discussion}

Identification and annotation of the $T$. japonicus ABC transporters

In this study, we identified $46 \mathrm{ABC}$ transporters in the copepod T. japonicus whole genome and RNA-Seq databases. All NBD-containing reads were examined by BLAST search to the non-redundant (NR) database of NCBI. To annotate each subfamily, full-length $A B C$ sequences were obtained from in silico analysis and/or the RACE method, and entire $T$. japonicus $A B C$ genes were subsequently registered in GenBank (Table 1, Additional file 1). Thus, this is the first report on the cloning and characterization of the entire $\mathrm{ABC}$ superfamily in copepods. Full-length $A B C$ proteins were ranged in size from 3124 amino acids (ABCA13) to 603 amino acids (ABCD4 isoform $\mathrm{X} 1$ ). In our preliminary phylogenetic analysis (Figure 1), $46 T$. japonicus $A B C$ genes were separated into eight subfamilies named A to $\mathrm{H}$, which were confirmed by Sturm et al. [7]. To analyze the evolutionary placement of the $46 T$. japonicus $A B C$ genes, in-depth phylogenetic analyses were conducted for each subfamily in comparison to those of yeast ( $S$. cerevisiae), worm (C. elegans), fruit fly (D. melanogaster), and human (H. sapiens) based on the criteria of Sturm et al. [7] (Additional files 2, 3, 4, 5, 6, 7 and 8). As discussed below, this kind of in-depth phylogenetic analysis allows evaluation of the evolutionary distance of each $T$. japonicus ABC transporter across the different families.

All T. japonicus ABC transporters possessed one or two conserved NBDs in their amino acid sequences (Figure 2). Of them, there were 21 full transporters (46\%) and 19 half 
Table 1 Information on 46 ABC transporters identified in the T. japonicus genome

\begin{tabular}{|c|c|c|c|c|c|c|}
\hline Gene & $\begin{array}{l}\text { Length } \\
\text { (AA) }\end{array}$ & $\begin{array}{l}\text { Accession } \\
\text { no. }\end{array}$ & Matched gene & Matched species & E-value & $\begin{array}{l}\text { Real-time RT-PCR primer } \\
\left(5^{\prime} \rightarrow 3^{\prime}\right)\end{array}$ \\
\hline ABCA1 & 2428 & KF906264 & ABCA1 (XP003747270) & Metaseiulus occidentalis & 0 & $\begin{array}{l}\text { F: CGGCAGGTCTTATGAGTTTC } \\
\text { R: CATTGTAAGTTTGGATTTGGG }\end{array}$ \\
\hline$A B C A 3$ isoform $X 1$ & 1541 & KF906265 & ABCA3 (EKC30762) & Crassostrea gigas & 0 & $\begin{array}{l}\text { F: TGATTCTGTGCCCTACTACTTG } \\
\text { R: GAGATGGGTGATTGGTGAAG }\end{array}$ \\
\hline$A B C A 3$ isoform $X 2$ & 1808 & KF906266 & ABCA3 (XP001851801) & Culex quinquefasciatus & 0 & $\begin{array}{l}\text { F: TAGTTATGACACGGAGGTTGC } \\
\text { R: TGAATAGTTGGTATGAACAGGG }\end{array}$ \\
\hline ABCA5 & 1781 & KF906267 & ABCA5 (XP001607492) & Nasonia vitripennis & 0 & $\begin{array}{l}\text { F: GACAGCAATCAGATGGAGGA } \\
\text { R: CTTTCTTCCATTCCTCTGATTC }\end{array}$ \\
\hline ABCA13 & 3124 & KF906268 & ABCA13 (EFN62269) & Camponotus floridanus & 0 & $\begin{array}{l}\text { F: AGGTTTGTCTGAGGATGCTG } \\
\text { R: GTATTTTGGGTCAATGTGCC }\end{array}$ \\
\hline ABCB1 (Full transporter) & 1361 & KF906269 & ABCB1 (AFS49708) & Tigriopus japonicus & 0 & $\begin{array}{l}\text { F: GTGATGATTATTCTCTITGGTGAC } \\
\text { R: ATTGATTGCTGGAGTGTCGT }\end{array}$ \\
\hline ABCB6 (Half transporter) & 827 & KF906270 & ABCB6 (XP003485185) & Bombus impatiens & 0 & $\begin{array}{l}\text { F: CCTTATCAAATGCTTGGGTC } \\
\text { R: AGAATCCAAGTTGAATACACCC }\end{array}$ \\
\hline ABCB7 (Half transporter) & 692 & KF906271 & ABCB7 (XP001813375) & Tribolium castaneum & 0 & $\begin{array}{l}\text { F: AGCCTAAAGTCCAGAATAAAGTG } \\
\text { R: CAAACTGAGTCCGTTCAAGATA }\end{array}$ \\
\hline ABCB8 (Half transporter) & 676 & KF906272 & ABCB8 (EKC24099) & Crassostrea gigas & 0 & $\begin{array}{l}\text { F: TTATTCAAGGCTITCCAGACA } \\
\text { R: GAATGGTCGGATIITTGAGTA }\end{array}$ \\
\hline ABCB10 (Half transporter) & 665 & KF906273 & ABCB10 (XP005102782) & Aplysia californica & 0 & $\begin{array}{l}\text { F: ACTTCGGCAGGATTTATTTG } \\
\text { R: GTTGCGTGTCTGATGAAAGTC }\end{array}$ \\
\hline$A B C C 1$ isoform $X 1$ & 1493 & KF906274 & ABCC1 (XP003243122) & Acyrthosiphon pisum & 0 & $\begin{array}{l}\text { F : ACGGGAAGTATCATCAATCG } \\
\text { R: GATGACAATGAGGACGGATG }\end{array}$ \\
\hline$A B C C 1$ isoform $X 2$ & 1515 & KF906275 & ABCC1 (XP001604021) & Nasonia vitripennis & 0 & $\begin{array}{l}\text { F: TTATCCTTCCAGTTATTGACCTT } \\
\text { R: AGCAGAGAGCACACACATAGG }\end{array}$ \\
\hline$A B C C 1$ isoform $X 3$ & 1497 & KF906276 & ABCC1 (XP003426122) & Nasonia vitripennis & 0 & $\begin{array}{l}\text { F: TCATACTCAGTTACTATCCTCTT } \\
\text { R: AAGGTCAGCAAGGATGGATA }\end{array}$ \\
\hline$A B C C 1$ isoform $X 4$ & 1513 & KF906277 & ABCC1 (XP005176239) & Musca domestica & 0 & $\begin{array}{l}\text { F: GGGGAAACTGTGAATCTTATGT } \\
\text { R: TAGGAAAGCCAAGGACAAGA }\end{array}$ \\
\hline$A B C C 1$ isoform $X 5$ & 1509 & KF906278 & ABCC1 (XP001604021) & Nasonia vitripennis & 0 & $\begin{array}{l}\text { F: GTGTCAATCGTAACATTCCGT } \\
\text { R: GTTTCACGAAGAGGAGGATT }\end{array}$ \\
\hline$A B C C 1$ isoform $X 6$ & 1476 & KF906279 & ABCC1 (XP003243122) & Acyrthosiphon pisum & 0 & $\begin{array}{l}\text { F: CAGTGCCACAGTTTCTACCAT } \\
\text { R: ACAACTTCAGACTCTTCCGATAG }\end{array}$ \\
\hline$A B C C 1$ isoform $X 7$ & 1533 & KF906280 & ABCC1 (XP001604021) & Nasonia vitripennis & 0 & $\begin{array}{l}\text { F: TGATGAAGAGGCTATGATTGG } \\
\text { R: AGAGGAGAAACGAGATAACGC }\end{array}$ \\
\hline$A B C C 1$ isoform $X 8$ & 1436 & KF906281 & ABCC1 (XP006119649) & Pelodiscus sinensis & 0 & $\begin{array}{l}\text { F: TCAAGAACAAGGACGAGAGG } \\
\text { R: CTTCAATGTTCGGTATCCC }\end{array}$ \\
\hline$A B C C 1$ isoform $X 9$ & 1611 & KF906282 & ABCC1 (XP003426121) & Nasonia vitripennis & 0 & $\begin{array}{l}\text { F: TCTCTTGGTTTACGGGTTTG } \\
\text { R: GAAACACGAAGCGACTCATC }\end{array}$ \\
\hline$A B C C 1$ isoform $X 10$ & 1523 & KF906283 & ABCC1 (XP001604021) & Nasonia vitripennis & 0 & $\begin{array}{l}\text { F: CAACGAGAGTCCAAACGAAC } \\
\text { R: GGAAACAAGTGGTGAAATCG }\end{array}$ \\
\hline$A B C C 2$ isoform $X 1$ & 1346 & KF906285 & ABCC1 (XP004770550) & Mustela putorius furo & $7 E-116$ & $\begin{array}{l}\text { F: AGTATTCTCTCTCCGCATTCTC } \\
\text { R: TGCCAATAAGGAGAGTGTAATG }\end{array}$ \\
\hline$A B C C 2$ isoform $X 2$ & 1380 & KF906286 & ABCC1 (XP004580304) & Ochotona princeps & 0 & $\begin{array}{l}\text { F: ATTAGCCAGTAAGAAGTTGAAGG } \\
\text { R: GTCGTTCCCAAACATTCATC }\end{array}$ \\
\hline $\mathrm{ABCC} 4$ & 1386 & KF906287 & ABCC4 (XP002939329) & Xenopus tropicalis & 0 & $\begin{array}{l}\text { F: AGTATTCCTAAGTTGGTTTGTGG } \\
\text { R: ACGGATGATGAGTGAAGGTG }\end{array}$ \\
\hline$A B C C 5$ & 1422 & KF906288 & ABCC5 (XP005051248) & Ficedula albicollis & 0 & $\begin{array}{l}\text { F: TCAACAACCCTACACTTCCTG } \\
\text { R: GCAGACAAGAGCGATGATTT }\end{array}$ \\
\hline$A B C C 7$ & 1496 & KF906289 & ABCC7 (ELT97351) & Acromyrmex echinatior & 0 & $\begin{array}{l}\text { F: CAAATGACCCTCAACGAACT } \\
\text { R: AGATACCGATGGAGAAAAACC }\end{array}$ \\
\hline$A B C C 9$ & 1949 & KF906290 & ABCC9 (XP003698789) & Apis florea & $4 \mathrm{E}-135$ & $\begin{array}{l}\text { F: TTGGGTCTGTTATCATTCTGG } \\
\text { R: ACGAGTTGAAGCAAGGTGAG }\end{array}$ \\
\hline
\end{tabular}


Table 1 Information on 46 ABC transporters identified in the $T$. japonicus genome (Continued)

\begin{tabular}{|c|c|c|c|c|c|c|}
\hline ABCC-like & 1296 & KF906284 & ABCC1 (XP001341895) & Danio rerio & 0 & $\begin{array}{l}\text { F: GAAAAACGATAAGGCTGGTG } \\
\text { R: CTATCCCAACTITCTGACCG }\end{array}$ \\
\hline ABCD2 & 736 & KF906291 & ABCD2 (XP001943381) & Acyrthosiphon pisum & 0 & $\begin{array}{l}\text { F: GATGACGAAGAGACGACAATG } \\
\text { R: GTCGTTGAAGCCTITCTATGA }\end{array}$ \\
\hline$A B C D 4$ isoform $X 1$ & 603 & KF906292 & ABCD4 (XP004699087) & Echinops telfairi & $4 \mathrm{E}-153$ & $\begin{array}{l}\text { F: AATGGAACTGGTCTGATGTGA } \\
\text { R: ACAAGGACAAGGCTGAAGTG }\end{array}$ \\
\hline$A B C D 4$ isoform $X 2$ & 608 & KF906293 & ABCD4 (XP005021486) & Anas platyrhynchos & 7E-169 & $\begin{array}{l}\text { F: ATCAGTTACTACACCTATTCGGC } \\
\text { R: CACGGGCGACATAAGTAGTT }\end{array}$ \\
\hline ABCE1 & 611 & KF906294 & ABCE1 (XP003690922) & Apis florea & 0 & $\begin{array}{l}\text { F: ACGAACCCTCTGCTTATTTG } \\
\text { R: GCTCCACGATAAAACCTGTC }\end{array}$ \\
\hline$A B C F 1$ & 820 & KF906295 & ABCF1 (XP004531105) & Ceratitis capitata & 0 & $\begin{array}{l}\text { F: CGAGAGTGAAGATGAAGACCA } \\
\text { R: ATTCTTGCCTTCTTGTCCT }\end{array}$ \\
\hline ABCF2 & 642 & KF906296 & ABCF2 (XP003403104) & Bombus impatiens & 0 & $\begin{array}{l}\text { F: GATTTGGAGGCTTGTGTCTG } \\
\text { R: TCCAGATGAATGATGTTGCTAC }\end{array}$ \\
\hline ABCF3 & 711 & KF906297 & ABCF3 (XP004923267) & Bombyx mori & 0 & $\begin{array}{l}\text { F: AATGTTGCTCAAGAAGATGGA } \\
\text { R: GGCTITGGCATCTIIITTAC }\end{array}$ \\
\hline ABCG_125057 & 687 & KF906298 & ABCG (XP003489743) & Bombus impatiens & 0 & $\begin{array}{l}\text { F: TTATCGGCACACTCACTCCT } \\
\text { R: ACACTATCCACACGAGCCAT }\end{array}$ \\
\hline ABCG_90506 & 659 & KF906299 & ABCG (EFX83517) & Daphnia pulex & 0 & $\begin{array}{l}\text { F: GGAAACGGTAATGAATCTGG } \\
\text { R: GGATTCTTGATAACAGATAACCAG }\end{array}$ \\
\hline ABCG_75152 & 651 & KF906300 & ABCG (XP_003398687) & Bombus terrestris & 0 & $\begin{array}{l}\text { F: GTTACTAAAGAACCTCTCATTGC } \\
\text { R: CCTTCTTGATTATTTCTTGTCC }\end{array}$ \\
\hline ABCG_105304 & 656 & KF906301 & ABCG (NP001034521) & Tribolium castaneum & 0 & $\begin{array}{l}\text { F: ATGTATTCACACGGGAGACG } \\
\text { R: TACACAGCACGACAAATCCA }\end{array}$ \\
\hline$A B C G 1$ & 767 & KF906302 & ABCG1 (EGI70628) & Acromyrmex echinatior & 0 & $\begin{array}{l}\text { F: TGAGACAAACTTGAAAGAGAAAC } \\
\text { R: ACACCTTCGGAGTTGTATGC }\end{array}$ \\
\hline$A B C G 5$ isoform $X 1$ & 656 & KF906303 & ABCG5 (XP003748075) & Metaseiulus occidentalis & $1 \mathrm{E}-170$ & $\begin{array}{l}\text { F: ATTACCAACATCTCTCAAACACC } \\
\text { R: TCCACTTAGCGACCTCCTTA }\end{array}$ \\
\hline$A B C G 5$ isoform $X 2$ & 822 & KF906304 & ABCG5 (XP003694147) & Apis florea & $2 \mathrm{E}-141$ & $\begin{array}{l}\text { F: CTATCCATCCACCAACTTACG } \\
\text { R: CAAGGATAGTCAATGAAGGCA }\end{array}$ \\
\hline ABCH_139282 & 768 & KF906305 & ABCH (EFX78467) & Daphnia pulex & 0 & $\begin{array}{l}\text { F: TGAGAAAGTTGCCTCTGGTC } \\
\text { R: GATGGCTTGAATGCTGTAGTC }\end{array}$ \\
\hline ABCH_88708 & 788 & KF906306 & ABCH (EFX78468) & Daphnia pulex & 0 & $\begin{array}{l}\text { F: CAAACACAGCCATCTCCTTC } \\
\text { R: GTAGATGGCACCTTTGGAA }\end{array}$ \\
\hline ABCH_103004 & 778 & KF906307 & ABCH (EFX78468) & Daphnia pulex & 0 & $\begin{array}{l}\text { F: GTTGTGTITGGTGTTCCTCC } \\
\text { R: TTGAGTGGCATCTTGTTGAGT }\end{array}$ \\
\hline ABCH_55580 & 723 & KF906308 & ABCH (EFX78468) & Daphnia pulex & 0 & $\begin{array}{l}\text { F: ATCTATCAACTGCCCACTGC } \\
\text { R: TTCCCATCTCCTCAGTGTTG }\end{array}$ \\
\hline ABCH_68644 & 714 & KF906309 & ABCH (EFX71377) & Daphnia pulex & $4 \mathrm{E}-88$ & $\begin{array}{l}\text { F: TCCTCGGTTATTGATTCTCG } \\
\text { R: CAAATAGTGTGTGGTGATGAGG }\end{array}$ \\
\hline
\end{tabular}

transporters (41\%). Particularly, the ABCA, ABCB, and $A B C C$ subfamilies contained full transporters, while the $\mathrm{ABCB}, \mathrm{ABCD}, \mathrm{ABCG}$, and $\mathrm{ABCH}$ subfamilies possessed half transporters. However, the $\mathrm{ABCE}$ and $\mathrm{ABCF}$ subfamilies did not contain TMDs. In T. japonicus, the vast majority of $\mathrm{ABC}$ transporters are in the $\mathrm{ABCC}$ subfamily (37\%), followed by the ABCG subfamily (15\%) (Figure 3, Table 2). The composition rate and percentage rank of $T$. japonicus $\mathrm{ABC}$ transporters were similar to those of T. castaneum, T. urticae, and B. mori, which have large numbers of $\mathrm{ABCs}$ in the $\mathrm{ABCC}(48,38$, and 27\%) and ABCG $(18,22$, and 24\%) subfamilies, respectively. Overall, the compositions of all $\mathrm{ABC}$ transporters showed different distributions for each animal subfamily analyzed in this study (Figure 3, Table 2). However, interestingly, similar percentage compositions were observed in the subfamilies of the insect $A B C C$ and ABCG subfamilies, while high numbers of $A B C$ proteins were observed in the $\mathrm{ABCB}$ and $\mathrm{ABCC}$ families of two fish species and humans (Figure 3), suggesting that the lineage-specific diversity of $\mathrm{ABC}$-related pathways has accumulated over evolution in a wide range of animal taxa. It also demonstrates that each animal has evolved a unique function for $\mathrm{ABC}$ transporters in response to different environmental and ecological conditions. Incomplete genomic sequence databases of certain animals affects our knowledge of the 


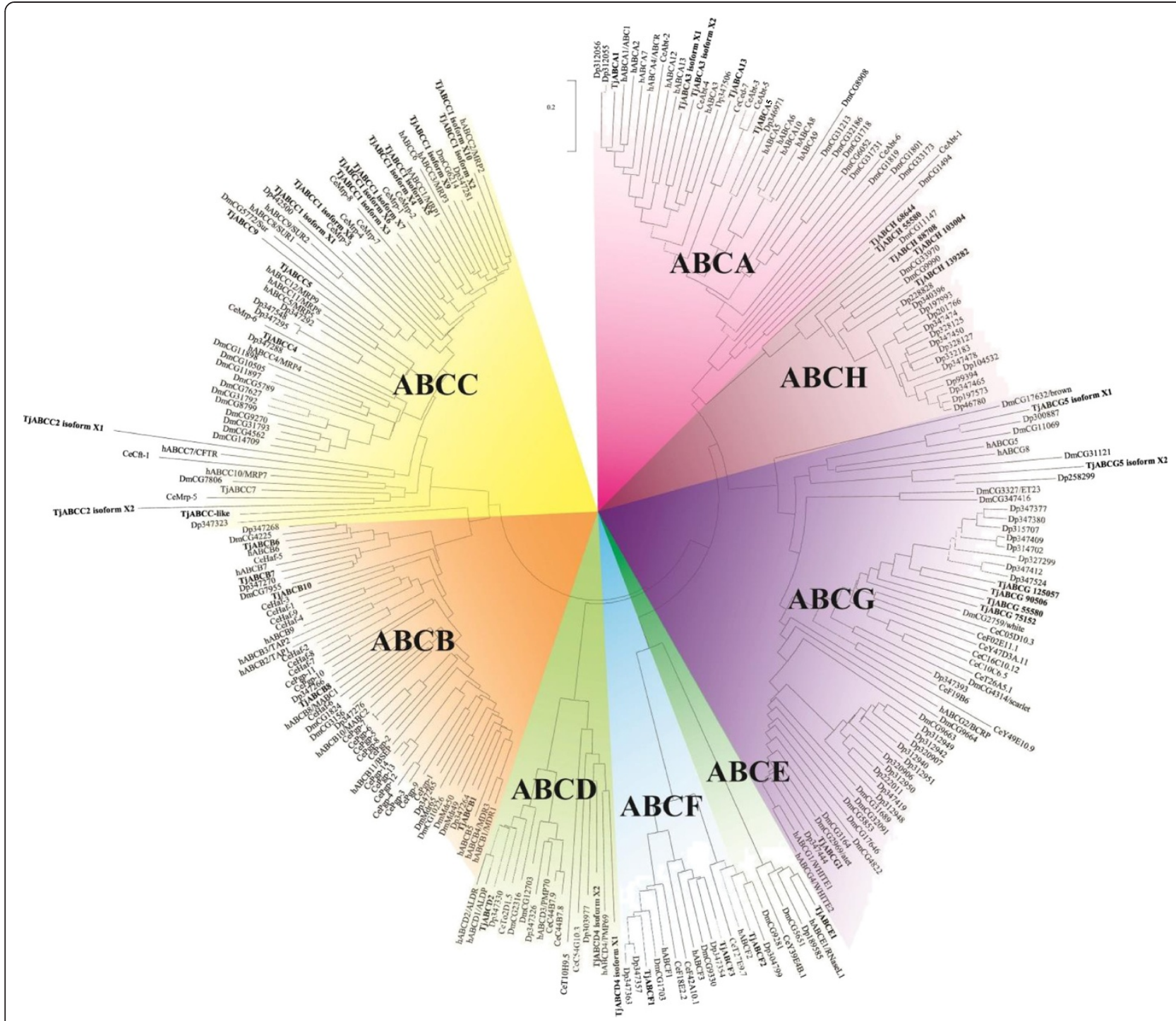

Figure 1 Phylogenetic analysis of $46 T$. japonicus ABC transporters using the Bayesian method. Numbers at branch nodes represent the confidence level of posterior probability.

annotation of $\mathrm{ABC}$ transporters and comparative composition analysis; only draft genome information is available for several animals including insects [9].

\section{ABCA}

Five ABCA proteins were identified in T. japonicus RNA-Seq and genome databases and were classified with phylogenetic analysis to provide their annotations (Additional file 2, Table 1). To date, the ABCA subfamily has been characterized by $\mathrm{NBD}(\mathrm{s})$, a conserved regulatory domain with multiple phosphorylation sites, and a large extracellular loop between the first two transmembrane (TM) helices in the TMD [19]. In T. japonicus, there are $4 \mathrm{ABCA}$ full transporters (two TMDs and two NBDs) and one single NBD-containing $\mathrm{ABCA}$ protein (two TMDs and one NBD; ABCA3 isoform X1) (Figure 2).
The human $\mathrm{ABCA}$ subfamily has full transporters, but no $A B C A$ protein has been identified in yeast $[1,20]$. The water flea $D$. pulex contains four ABCA full transporters [7]. The ABCA subfamily in the silkworm consists of two full transporters, one half transporter, and three single NBD-containing incomplete $A B C$ proteins [9]. Thus, in animals, $\mathrm{ABCA}$ proteins show great domain variation among species due to duplication and insertion and/or deletion via evolution.

Regarding the potential function of the ABCA subfamily, there is still little information on the function of $A B C A$ proteins in invertebrates. Mammalian ABCA proteins are involved in control of the cellular lipid transport processes and have several potential roles in lipoprotein biogenesis, lung surfactant production, retinal integrity, and skin lipid barrier formation [21]. In invertebrates, Broehan et al. 


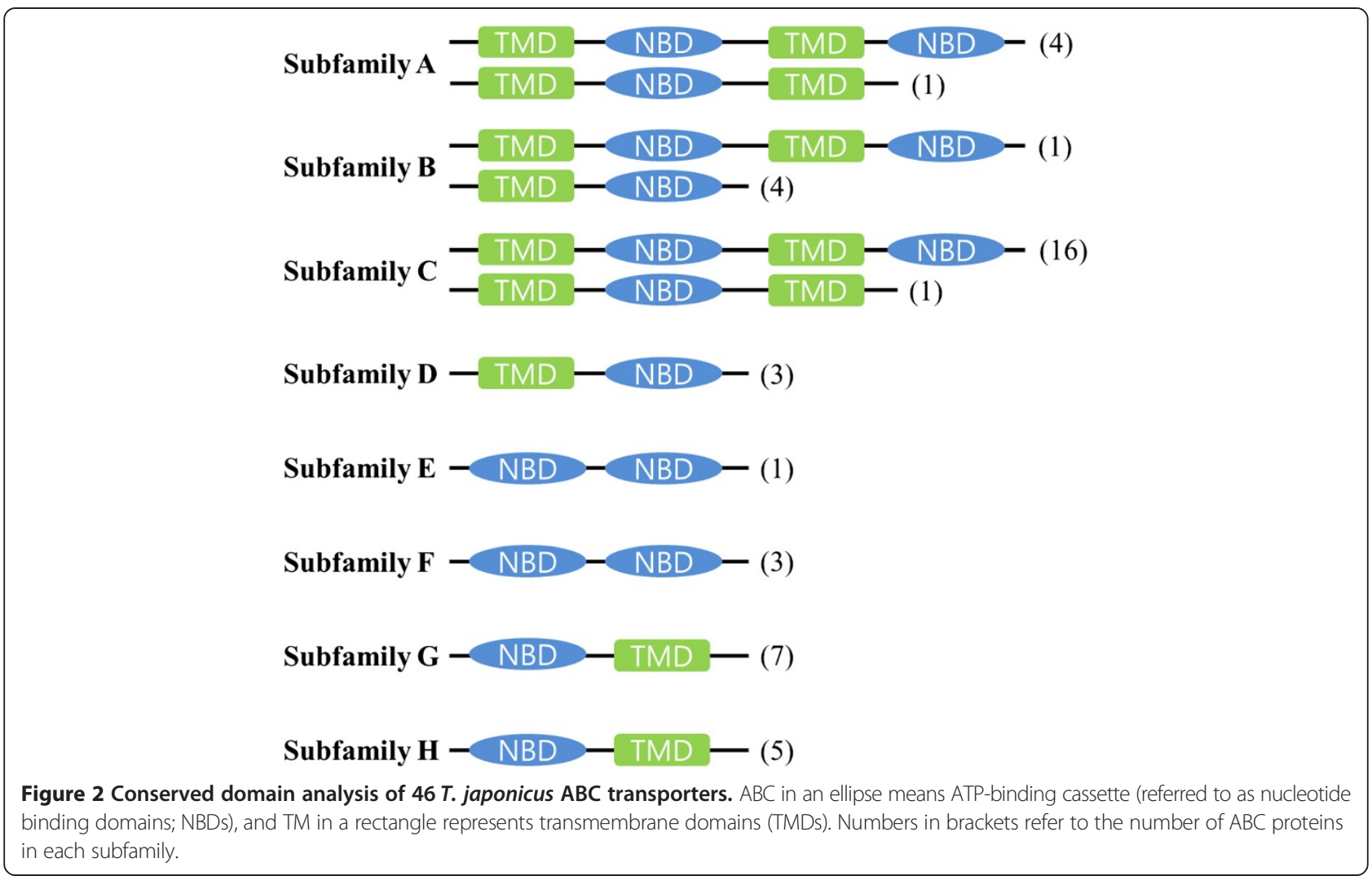

[12] used the flour beetle $T$. castaneum to perform an RNAi screen for TcABCA-9A and TcABCA-9B and found $\sim 30 \%$ stage-specific mortality with severe defects in the development of wings and elytra, leaving the functional role unknown in invertebrate ABCA proteins. Comparison of domains and other components among arthropods is necessary to better understand the "gain/loss of gene function" scenario of the ABCA subfamily from the evolutionary perspective of crustaceans, including copepod and Daphnia to insects and vertebrates.

\section{ABCB}

The ABCB subfamily is divided into a group of full transporters (two TMDs and two NBDs) and a group of half transporters (one TMD and one NBD). In T. japonicus, five $\mathrm{ABCB}$ proteins were identified, and each had distinct clades with regard to phylogenetic distance (Additional file 3 , Table 1 ). The $T$. japonicus $\mathrm{ABCB}$ subfamily consisted of one full transporter (ABCB1) and four half transporters (Figure 2). The TJ-ABCB1 protein, a P-glycoprotein (P-gp), is most well-characterized member of the mammalian multidrug transport process. As shown in Additional file 3 , the $T J-A B C B 1$ gene was clearly clustered with other $A B C B 1 / P-g p / M D R 1$ genes in phylogenetic analysis, suggesting that the TJ-ABCB1 protein is involved in biochemical defense against diverse molecules including xenobiotics, as suggested in other invertebrates. While we identified only a single P-gp gene in T. japonicus, Sturm et al. [7] reported three ABCB full transporters ( $m d r 49$, $m d r 50$, and $m d r 65$ ) and two full transporters in the fruit fly $D$. melanogaster and the water flea $D$. pulex, respectively. The silkworm $B$. mori also has multiple types of $A B C B 1 / P$-gp/MDR1 genes [9].

The $T$. japonicus half transporters (TJ-ABCB6, TJ$\mathrm{ABCB} 7, \mathrm{TJ}-\mathrm{ABCB} 8$, and $\mathrm{TJ}-\mathrm{ABCB} 10$ proteins) form a robust clade (Additional file 3), indicating that these proteins have clear orthologous relationships with those of the fruit fly and human, as shown in a previous study with D. pulex [7]. This also suggests that the four T. japonicus half transporter proteins have similar roles to the $\mathrm{ABCB}$ half transporter proteins of arthropods and humans. In humans, these $\mathrm{ABCB}$ transporter proteins are mitochondrial transporters with roles in porphyrin transport, Fe-S cluster assembly, and modulation of mitochondrial reactive oxygen species [22-25]. Since these processes are common to all eukaryotic systems, conservation of these proteins in $T$. japonicus is to be expected. These proteins may have additional roles because the $\mathrm{ABCB}$ half transporter in D. melanogaster, CG4225, is orthologous to TJ-ABCB6 and has been shown to confer tolerance to cadmium [26].

\section{$\mathrm{ABCC}$}

The ABCC subfamily consists of the chloride channel cystic fibrosis transmembrane conductance regulator (CFTR), 


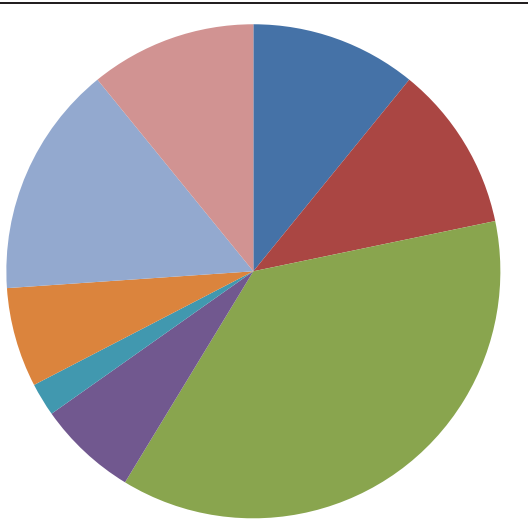

\section{T. japonicus}

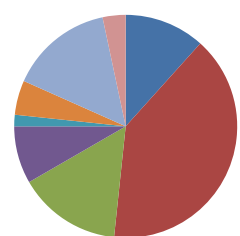

C. elegans

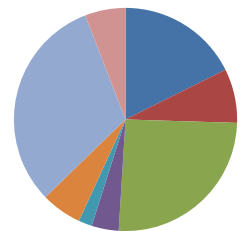

A. gambiae

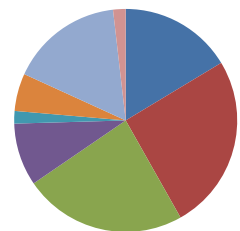

D. rerio

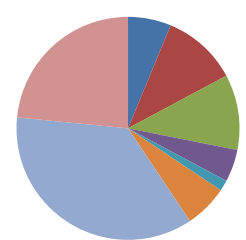

D. pulex

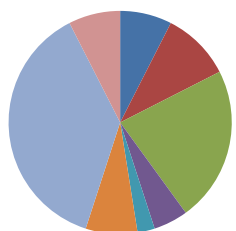

A. mellifera

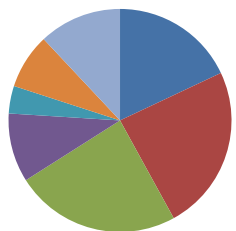

I. punctatus

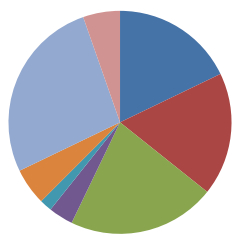

D. melanogaster

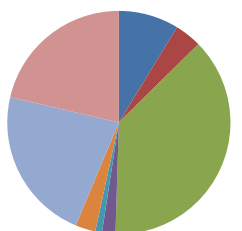

T. urticae

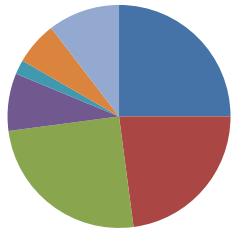

H. sapiens

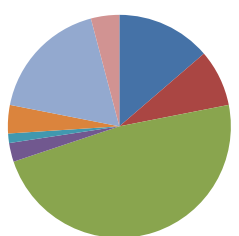

\section{T. castaneum}

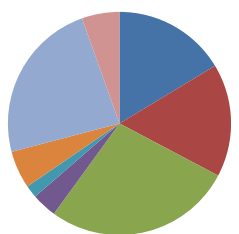

B. mori

Figure 3 Comparison of the number of genes in each subfamily of ABC transporters between $T$. japonicus and other animals.

membrane-bound sulfonylurea receptors (SUR1 and SUR2), and several multidrug resistance-associated proteins (MRPs) that are involved in transporting drugs, ions, toxins, and endogenous compounds $[1,27,28]$. In $T$. japonicus, we identified $17 \mathrm{ABCC}$ transporters consisting of 16 full transporters (two TMDs and two NBDs) and one short form transporter (two TMDs and one NBD) (Figure 2, Additional file 4, Table 1). The D. pulex and D. melanogaster $\mathrm{ABCC}$ subfamilies contained seven full transporters as in the human $\mathrm{ABCC}$ subfamily [7], while other insects such as A. gambiae, A. mellifera, B. mori, and T. castaneum showed different numbers of full, half, and incomplete
ABCC transporters [9]. In the T. japonicus ABCC subfamily, $10 \mathrm{TJ}-\mathrm{ABCC}$ proteins were identified as $\mathrm{ABCC} 1$ isoforms, suggesting that the TJ-ABCC1 subfamily is highly divergent based on adaptation to environmental stress. All TJ-ABCC1 isoforms were clustered in a clade with human "long" MRPs and D. melanogaster CG6214, as shown in Additional file 4.

One of the ABCC subfamilies, TJ-ABCC4, was clustered with human ABCC4 (MRP4), which is involved in removal of a wide range of endogenous and xenobiotic organic anionic compounds from the cell with a potential function in extracellular signaling pathways [29]. In 
Table 2 Number of ABC transporters in different animals and the composition in each ABC subfamily

\begin{tabular}{|c|c|c|c|c|c|c|c|c|c|c|c|c|}
\hline & $\begin{array}{c}C . \\
\text { elegans } \\
{[6]}\end{array}$ & $\begin{array}{c}T . \\
\text { japonicus }\end{array}$ & $\begin{array}{l}D . \\
\text { pulex } \\
{[7]}\end{array}$ & $\begin{array}{c}D . \\
\text { melanogaster } \\
{[1]}\end{array}$ & $\begin{array}{c}T . \\
\text { castaneum } \\
{[12]}\end{array}$ & $\begin{array}{c}A . \\
\text { gambiae } \\
{[8,9]}\end{array}$ & $\begin{array}{c}A . \\
\text { mellifera } \\
{[9,10]}\end{array}$ & $\begin{array}{c}T . \\
\text { urticae } \\
{[11]}\end{array}$ & $\begin{array}{c}\text { B. } \\
\text { mori } \\
{[9]}\end{array}$ & $\begin{array}{l}D . \\
\text { rerio } \\
{[13]}\end{array}$ & $\begin{array}{c}\text { I. } \\
\text { punctatus } \\
{[57]}\end{array}$ & $\begin{array}{c}H . \\
\text { sapiens } \\
\text { [1] }\end{array}$ \\
\hline A & 7 & 5 & 4 & 10 & 10 & 9 & 3 & 9 & 9 & 9 & 9 & 12 \\
\hline B & 24 & 5 & 7 & 10 & 6 & 5 & 5 & 4 & 9 & 14 & 12 & 11 \\
\hline$C$ & 9 & 17 & 7 & 12 & 35 & 13 & 9 & 39 & 15 & 13 & 12 & 12 \\
\hline$D$ & 5 & 3 & 3 & 2 & 2 & 2 & 2 & 2 & 2 & 5 & 5 & 4 \\
\hline $\mathrm{E}$ & 1 & 1 & 1 & 1 & 1 & 1 & 1 & 1 & 1 & 1 & 2 & 1 \\
\hline$F$ & 3 & 3 & 4 & 3 & 3 & 3 & 3 & 3 & 3 & 3 & 4 & 3 \\
\hline $\mathrm{G}$ & 9 & 7 & 24 & 15 & 13 & 16 & 15 & 23 & 13 & 9 & 6 & 5 \\
\hline $\mathrm{H}$ & 2 & 5 & 15 & 3 & 3 & 3 & 3 & 22 & 3 & 1 & 0 & 0 \\
\hline Total & 60 & 46 & 65 & 56 & 73 & 52 & 41 & 103 & 55 & 55 & 50 & 48 \\
\hline
\end{tabular}

addition, the TJ-ABCC9 protein clustered with human SURs (ABCC8 and ABCC9) and the fruit fly SUR protein (CG5772), indicating that TJ-ABCC9 is a SUR homolog.

\section{ABCD}

Peroxisomes are involved in a variety of metabolic processes including $\beta$-oxidation of fatty acids. The ABCD subfamily members are peroxisomal transporters, and they actively participate in the transport of fatty acids and/or acyl-CoA with different substrate specificities in mammalian peroxisomes [30]. To date, in diverse animal taxa, all ABCD subfamilies are known to be half transporters and dimerize primarily as homodimers to function as transporters at the cellular level. In T. japonicus, we annotated three TJ-ABCD transporters including one ABCD2 and two isoforms of ABCD4 (Figure 2, Additional file 5, Table 1). There is no information on function in the invertebrate $A B C D$ subfamily, but in humans, they have roles in fatty acid metabolism and pathological processes of neurodegenerative disease [31]. Based on phylogenetic analysis, each TJ-ABCD transporter showed a clear homologous relationship to that of humans, indicating that such genes may share similar functions across the animal kingdom. To date, copepod fatty acids and their metabolites have been intensively studied as a useful food source for fish larvae. Interestingly, copepods accumulate wax esters in their oil sac for energy reservation and buoyancy, and the high contents of fatty acids are a primary food source for fish, sea birds, and whales [32,33]. These wax esters are used for gonadal development in female copepods and for physical activity in males [33]. Teerawanichpan and Qiu [34] identified three fatty acylCoA reductases that are responsible for de novo synthesis of fatty alcohol moieties of wax esters in the marine copepod Calanus finmarchicus. Therefore, general roles and/ or specific functions of the ABCD subfamily may be highlighted in copepods, as their nutritional aspects are very important in aquaculture.

\section{$A B C E$ and $A B C F$}

The subfamilies of $\mathrm{ABCE}$ and $\mathrm{ABCF}$ contain a pair of linked NBDs and no TMD segment, which is commonly found in other members of the subfamily. Therefore, both subfamilies are known to play a biological role that does not include transmembrane functions. This unique structural character was also observed in both $\mathrm{ABCE}$ and $\mathrm{ABCF}$ subfamilies of T. japonicus (Figure 2). Phylogenetic analysis revealed that all TJ-ABCE and ABCF transporters formed a unique cluster similar to those of insect and human (Additional file 6), suggesting that they have conserved roles during evolution. In the case of the T. japonicus ABCE subfamily, a single transporter (TJ-ABCE1) was identified, as shown in other $\mathrm{ABC}$ superfamilies of diverse animal taxa (Table 2). The ABCE transporters are believed to be involved in inhibition of ribonuclease $\mathrm{L}$, translation initiation, ribosome biosynthesis, tumor cell proliferation, and anti-apoptosis [35,36]. In invertebrates, the $\mathrm{ABCE}$ transporter has not been well characterized, but a recent report showed that RNAi-mediated knockdown of a flour beetle $A B C E$ gene (TCABCE-3A) caused defects in pupation, resulting in significant mortality in penultimate larvae of the flour beetle T. castaneum [12]. Moreover, eukaryotic $\mathrm{ABCE} 1$ contains a unique structural organization in the $\mathrm{N}$-terminal region with eight conserved cysteines, which are predicted to coordinate diamagnetic iron-sulfur clusters $(\mathrm{Fe}-\mathrm{S})^{2}$ [37]. Iron-sulfur clusters constitute an ancient prosthetic group that is found in diverse proteins from all living animals, and they are essential for the enzymatic function involved in electron transport for a variety of cellular processes. In the TJ-ABCE1 protein, there are two essential iron-sulfur clusters with different electronic environments, one ferredoxin-like $\left(\mathrm{CPX}_{24} \mathrm{CX}_{2} \mathrm{CX}_{2} \mathrm{C}\right.$; Cys at positions 4-7) and one unique ABCE1-type cluster $\left(\mathrm{CXPX}_{2} \mathrm{CX}_{3} \mathrm{CX}_{3} \mathrm{CP}\right.$; Cys at positions 1, 2, 3, and 8), suggesting that the TJ-ABCE1 protein is evolutionary conserved across the animal kingdom and is essential for copepod life. Thus, in copepods, ABCE1 has an obvious 
role in electron transport as well as potential roles in a wide range of activities including electron transport in respiratory chain complexes, regulatory sensing, photosynthesis, DNA repair, protein stability, and nucleic acid binding and modification [37-39].

In the case of the $\mathrm{ABCF}$ subfamily, three $\mathrm{ABCF}$ proteins were annotated and showed well-supported sister clades (Additional file 6, Table 2). To date, in most eukaryotes, including insects, three $\mathrm{ABCF}$ proteins have been identified $[9,10,16]$, suggesting that $A B C F$ subfamilies are highly conserved during evolution, as confirmed in T. japonicus. In yeast and human, $\mathrm{ABCF}$ proteins participate in gene regulation systems and ribosome assembly $[14,40]$, while RNAi-mediated knockdown of $T c A B C F-2 A$ induced $100 \%$ mortality in penultimate larvae of the flour beetle T. castaneum [12]. Based on the conserved domain structure, high similarity in amino acids, and distinct separation in phylogenetic analysis of ABCF subfamilies within animal taxa, we suggest that TJ-ABCF transporters have a potential role in translational regulation and/or cell viability.

\section{ABCG}

In the copepod T. japonicus, seven ABCG transporters were identified (Table 1). All T. japonicus ABCG proteins are half transporters that possess a reverse domain architecture (NBD-TMD), as shown in most metazoan species (Figure 2), while fungi and plants have additional full transporters [41,42]. As described in the ABCC subfamily, arthropods including $T$. japonicus contain a high composition of the ABCG subfamily, while humans and two species of fish have a variety of subfamilies in the $\mathrm{ABCA}, \mathrm{ABCB}$, and $\mathrm{ABCC}$ subfamilies (Figure 3). These different subfamily patterns in several taxa suggest that extensive gene duplication is lineage-specific for different $A B C$ subfamilies within arthropods and vertebrates (e.g., mammals, fish). In arthropods, this hypothesis was confirmed by comparison of the localization of paralogous or orthologous genes on chromosomes and with phylogenetic analysis [7,9-11]. For example, in the water flea D. pulex, Sturm et al. [7] showed the presence of pseudogenes of the ABCG subfamily by comparing expressed sequence tags (ESTs) with the gene loci of each putative ABCG proteins through in silico analysis.

Among invertebrates, the functions of several ABCG proteins were first characterized in Drosophila as pigment precursor transporters (brown, scarlet, and white genes) into pigment cells [43,44]. In silkworm, Kômoto et al. [45] reported that a single-base deletion in exon 2 and a premature stop codon at the $5^{\prime}$ end of exon 3 of a silkworm homolog (Bmwh3) of the D. melanogaster white gene caused white eyes, white eggs, and translucent larval skin in the silkworm $w-3^{o e}$ mutant. In phylogenetic analysis, four T. japonicus ABCG proteins showed an orthologous relationship with nine Daphnia ABCG proteins and the
Drosophila white protein, while no orthologous clone in T. japonicus was found for Drosophila brown or scarlet proteins (Additional file 7). A functional study with orthologs of the Drosophila white protein is necessary for a better understanding of copepod sensing mechanisms, as copepods have a single eyespot sensing illumination intensity, although we were not able to identify additional transporters for eye pigment transfer in T. japonicus. In addition, TJ-ABCG1 was in a clade with human ABCG1/ ABCG4 and the Drosophila atet protein, which is expressed in the trachea [46]. In humans, ABCG1 plays a role in controlling sterol homeostasis $[47,48]$, while several ABCG full transporters of the Indian-rock oyster S. forskali and the white shrimp Litopenaeus vannamei are involved in fungicide resistance and detoxification [49-51]. In D. melanogaster, the CG3327 transporter (also called E23, early gene at 23 ) is believed to be induced by $20-\mathrm{OH}$ ecdysone (20E), potentially through a $20 \mathrm{E}$ regulation mechanism [52], but the orthologous sequence was not identified in T. japonicus. Liu et al. [9] showed that 20E treatment regulated mRNA expression of the midgut-specific silkworm $A B C G$ genes, suggesting that midgut-specific $A B C G$ genes are closely related to $20 \mathrm{E}$. Future studies should focus on examining similar or compensatory function with identification of the transporter gene for $20 \mathrm{E}$ regulation in T. japonicus, as ecdysone has a conserved role in crustaceans [53]. In addition, there is molecular and biochemical evidence for an ecdysone receptor and its putative involvement in the ecdysone-triggered metabolism of T. japonicus [54].

\section{$\mathrm{ABCH}$}

The $A B C H$ proteins are an interesting $A B C$ subfamily that is only annotated in arthropods and zebrafish $[7,9,10,12,13,55]$ and has not yet been identified in fungi, plants, C. elegans, or mammals $[1,6,41,42]$. There are controversial reports on the presence of the $\mathrm{ABCH}$ subfamily in fish. After annotation of the $\mathrm{ABCH}$ proteins in zebrafish, Popovic et al. [56] showed a potential sequence of the $\mathrm{ABCH}$ subfamily in the green spotted pufferfish Tetraodon nigroviridis. However, Liu et al. [57] recently reported that the $\mathrm{ABCH}$ subfamily was identified in zebrafish but not in other fish such as catfish, medaka, fugu, stickleback, tetraodon, tilapia, cod, or coelacanths. Therefore, further analysis on evolutionary deletion or insertion of $\mathrm{ABCH}$ proteins may be helpful to clarify the situation in fish, especially since the $\mathrm{ABCH}$ subfamily was not identified in coelacanths, the most primitive fish. Regardless of the absence of the $\mathrm{ABCH}$ subfamily in fish aside from zebrafish, five $\mathrm{ABCH}$ proteins were identified as half transporters in T. japonicus (Figure 2, Table 1). Phylogenetic analysis showed that $T$. japonicus is a distinct clade of the $\mathrm{ABCH}$ subfamily (Additional file 8 ), indicating that this subfamily experienced lineage-specific 
accumulation by gene duplication, as suggested in the polyphagous spider mite [11]. However, Liu et al. [9] mentioned that insect $\mathrm{ABCH}$ subfamilies originated from a common ancestor based on the phylogenetic relationship, while this has not been confirmed in copepods or cladocerans. In fact, of the eight $\mathrm{ABC}$ subfamilies, $\mathrm{ABCH}$ proteins in the subfamily consist of many genes, as shown in D. pulex and T. japonicus, and these are located in different clades. As of yet, the physiological function of invertebrate $\mathrm{ABCH}$ proteins remains unclear, but several valuable reports have highlighted potential roles in insects. In Drosophila ABCH proteins, Dermauw et al. [10] summarized differentially expressed profiles of the CG9990 gene in different tissues and its potential role in survival using an RNAi-aided gene silencing screening method. Broehan et al. [12] showed using RNAi-mediated knockdown of the TCABCH-9C gene in T. castaneum that one of the $\mathrm{ABCH}$ proteins is a lipid transporter required for the maintenance of the waterproof barrier of the epicuticle.

\section{Transcriptional expression of all $A B C$ transporters in developmental stages}

In $T$. japonicus, we measured temporal transcriptional expression of all $\mathrm{ABC}$ transporters during developmental stages using a real-time RT-PCR (Figure 4). Developmental stages and the morphological phenotype in each stage are shown in Additional file 9. Overall, expression intensity was high in the $\mathrm{ABCE}$ to $\mathrm{ABCH}$ subfamilies (Figure 4, Additional file 10). Interestingly, $A B C$ genes of these four subfamilies are translated into short amino acid sequences and are composed of a unique domain structure, as described in each section. They are likely involved in cellular and biological processes other than transport. Therefore, we predict that these subfamilies individually play a role in the molecular physiology of different developmental stages of T. japonicus. Regarding stage-preferential transcript profile (Additional file 11), dramatic transcriptional change was not observed, but relatively low transcript intensities were observed in the NIII stage. The NIII stage (collecting naupliar stages 5 and 6) is important for molting prior to the copepodid stages. Diverse physiological and motional changes have been observed during the molting stage in copepods [58-60]. The naupliar stages are more sensitive to diverse environmental conditions including toxicants than are copepodid and adult stages [61-63]. Therefore, we concluded that several physiological metabolisms are highly activated in this stage, although this needs to be verified in future studies.

In all developmental stages of $T$. japonicus, the $T J$ $A B C H \_88708$ and $T J-A B C E 1$ genes are highly expressed (Additional file 10). However, in invertebrate development, the physiological or molecular function of $\mathrm{ABCH}$ remains generally unknown. In $D$. melanogaster, Zhang et al. [64] showed that one ABCH subfamily gene (CG9990) is involved in mortality, demonstrated by RNAi-mediated silencing. In T. castaneum, Broehan et al. [12] reported that injection of $T c A B C H-9 C$ gene-specific dsRNA arrested development and caused $100 \%$ mortality with morphological changes in the cuticle such as desiccation and shrinkage during the quiescent stage. Moreover, TcABCH-9C gene knock-down reduced the number of laying eggs in adult $T$. castaneum and also caused failure to hatch for all eggs. Cuticles are essential in copepods and provide an important interface against the environment as a skeletal structure. The cuticle can also act as a defense barrier against detrimental conditions such as pathogens, osmotic shock, and a number of environmental toxicants [65]. Therefore, it is likely that the TJ- $A B C H \_88708$ gene is involved in development-related metabolism such as a lipid transporter to the cuticle.

ABCCs showed differential expression patterns in developmental stages, and isoforms of $\mathrm{ABCC} 1$ and $\mathrm{ABCC} 2$ also showed unique transcriptional profiles (Figure 4). While their roles in the detoxification process have been noted, as ABCCs/MRPs share substrates for the ABCB1/ $\mathrm{P}$-gp/MDR1 protein and eliminate xenobiotics or metabolites by transporting glucuronate, sulfate, and glutathione (GSH) conjugates [50,66-68], several studies have suggested their participation in early cell division of embryos, development, oocyte maturation, and general physiology $[10,69,70]$. Based on the unique divergence of ABCCs in T. japonicus, we suggest that each isoform evolved as a new transporter for adaptation and/or speciation, even though pseudogenes should be confirmed with genomic structure comparison and functional characterization.

Three T. japonicus ABCDs showed slight changes in entire developmental stages (Figure 4). Since these ABCDs are homologous to those of mammal and insect transporters, similar functions such as roles in fatty acid metabolism can be inferred. Subsequently, modulation of ABCD transporters may be directly related to a variation in wax content and composition in different developmental stages of copepods [71].

Regarding the highly expressed $A B C E 1$ gene in $T$. japonicus, similar transcriptional profiles were observed in several insects, but there is limited information on the function of the ABCE subfamily in invertebrates. Liu et al. [9] reported that the silkworm $A B C E$ gene ( $B m A B C 010129)$ was highly expressed in the EST information. In the polyphagous spider mite $T$. urticae, one of the ABCE subfamily members (tetur30g01400 gene) showed very high expression in all developmental stages [11], while the TcABCE-3A transcripts in the flour beetle were highly abundant throughout all developmental stages [12]. In eukaryotes, the ABCE protein generally acts as a catalyst in the initiation and termination of translation and ribosome recycling, as described in the above ABCE section. Thus, we assume that 


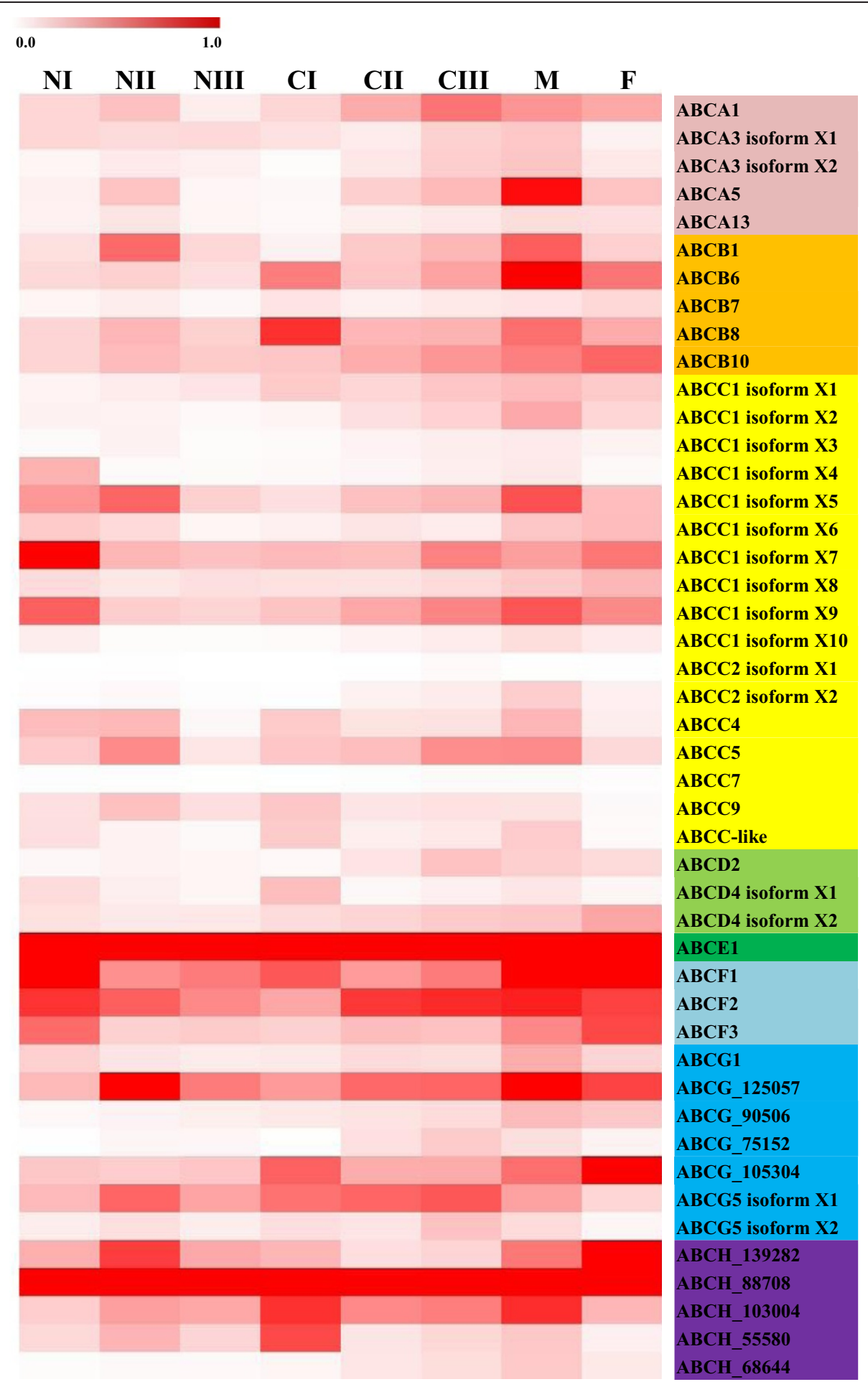

Figure 4 Temporal transcriptional expressions of $46 T$. japonicus $A B C$ transporters in different developmental stages (N, nauplius; C, copepodid; M, male; F, female).

ubiquitous TJ-ABCE1 plays a fundamental role in developmental processes in $T$. japonicus. In T. castaneum, injection of TCABCE-3A-specific dsRNA into penultimate larvae caused a lethal phenotype with $100 \%$ mortality, and the injection of TCABCE-3A-specific dsRNA into prepupae led to defects in pupation and $100 \%$ mortality [12]. Taken together, our results suggest that the $\mathrm{ABCE}$ transporter is essential for normal development of $T$. japonicus, 
as ABCE subfamilies are highly evolutionarily conserved with regard to both gene structure and role over all animal taxa $[37,72]$.

\section{Conclusion}

Only a few genomes have been sequenced in crustaceans, resulting in a lack of comparative genomic information, particularly for large gene families. In this study, we conducted a genome-wide analysis of the entire $\mathrm{ABC}$ transporters in the intertidal copepod $T$. japonicus and annotated and characterized $46 A B C$ genes as a first report in copepods. Our analysis provides new insight into the diversity of the entire $A B C$ subfamily in copepods compared with all arthropods. We anticipate that a functional study in the near future will elucidate the molecular and physiological functions of each $\mathrm{ABC}$ transporter in this species. The descriptive study of the T. japonicus $\mathrm{ABC}$ superfamily by genome sequencing, a genome-wide omics approach, and in silico analysis will reveal the evolutionary effects of genome duplication, particularly using the gene superfamily in T. japonicus.

\section{Methods}

\section{$T$. japonicus culture and maintenance}

The copepod T. japonicus was originally collected from a single rockpool at Haeundae beach $\left(35^{\circ} 9^{\prime} 29.57^{\prime \prime} \mathrm{N}\right.$, $129^{\circ} 9^{\prime} 36.60^{\prime \prime} \mathrm{E}$ ) in Busan (South Korea) in 2003; since then, we have continuously cultured them in a laboratory (the number of generation times $\approx 285$; Sungkyunkwan University, Suwon, South Korea) with filtered artificial sea water (TetraMarine Salt Pro, Tetra ${ }^{\mathrm{T}}$, Cincinnatti, $\mathrm{OH}$, USA) adjusted to $25^{\circ} \mathrm{C}$ and a photoperiod of $12 \mathrm{~h}: 12 \mathrm{~h}$ light/dark with a salinity of 30 practical salinity units (psu). The copepods were fed green algae, Chlorella sp. (approximately $6 \times 10^{4}$ cells/ml). Identification of $T$. japonicus was based on morphological characteristics and the sequence identity of the universal barcode marker, the mitochondrial DNA CO1 gene.

\section{Retrieval and annotation of whole $A B C$ transporters}

A T. japonicus genomic DNA database was constructed as shown in our previous study [17]. Briefly, we mechanically sheared the genomic DNA of $T$. japonicus into fragments and created a genomic DNA library according to the manufacturer's instruction (Roche Applied Science, Genome Sequencer System). Sequencing (by GS-FLX, Solexa, and Solexa mate pair), assembly, gene annotation, and GO analysis were performed at the NICEM, Seoul National University (Seoul, South Korea). Finally, we obtained a scaffold number of 60,979 (scaffold length $174,022,895 \mathrm{bp}$; average read length 2,854 bp; N50= $6,335 \mathrm{bp}$ ) covering approximately $174 \mathrm{Mb}$ of $T$. japonicus genomic DNA. For RNA seq, total RNAs of T. japonicus were sequenced using an RNA-seq platform (Illumina,
CA, US; 59,983 assembled ESTs; total length $78.3 \mathrm{Mb}$; $\mathrm{N} 50=2,319$ as of Feb. 10, 2014) and then assembled with NGS Cell (Ver. 4.06 beta 67189, CLC Bio, MA, USA) and Velvet (EMBL-EBI, UK) [17] software. To obtain the sequence information of all $\mathrm{ABC}$ transporters in T. japonicus genomic DNA and transcriptome databases, the obtained contigs and clones after assembly as well as genomic clones were subjected to BLAST analysis to the non-redundant (NR) database at GenBank (ftp://ftp.ncbi.nlm.nih.gov/blast/db/FASTA/nr.gz). To confirm exon/intron boundary and start/stop codons, genomic structure was mutuallycompared between the genomic clone and transcript for each gene. Some $A B C$ transporter sequences were subjected to 5 ' - and $3{ }^{\prime}$-RACEs according to the manufacturer's protocol (Invitrogen, Carlsbad, CA), as incomplete transcript information was observed in the $5^{\prime}$ and/or $3^{\prime}$ terminal region. Annotation and nomenclature of all $T$. japonicus $A B C$ genes were completed based on amino acid sequence similarities in terms of in silico domain analysis compared to ABC superfamilies of other animals. All gene information was registered to the GenBank database, and the accession numbers of each gene are appended in Table 1.

\section{Phylogenetic analysis}

To analyze the evolutionary placement of the copepod $T$. japonicus $A B C$ clusters on the phylogenetic tree, we aligned them with those of other species at the level of the deduced amino acid sequence by ClustalX 1.83. Selection of the $\mathrm{ABC}$ superfamily from a representative animal in each animal taxon followed the criteria of Sturm et al. [7]. Entire $A B C$ gene sets of yeast (Saccharomyces cerevisiae), worm (Caenorhabditis elegans), fruit fly (Drosophila melanogaster), and human (Homo sapiens) were obtained from the GenBank database. Gaps and sets with missing data were excluded from the analysis. The generated data matrix was converted to the nexus format and was analyzed with the Mr. Bayes v3.1.2 program using the general time-reversible (GTR) model. A total of 1,000,000 generations were conducted, and the sampling frequency was assigned as every 100 generations. After analysis, the first 10,000 generations were deleted as the burn-in process, and the consensus tree was constructed and then visualized with Tree View software of PHYLIP.

\section{Total RNA extraction and single-strand CDNA synthesis}

The morphological characteristics and developmental stages of the copepod T. japonicus were analyzed based on the criteria of Raisuddin et al. [16] (Additional file 9). Whole bodies $(\approx 500$ individuals for each developmental stage of nauplius and copepodid; $\approx 300$ adult individuals) were homogenized in three volumes of TRIZOL ${ }^{\oplus}$ reagent (Molecular Research Center, Inc.) with a tissue grinder 
and stored at $-80^{\circ} \mathrm{C}$ until use. Total RNA was extracted according to manufacturers' instructions and stored at $-80^{\circ} \mathrm{C}$ until use. DNA digestion was performed using DNase I (Sigma, St. Louis, Mo). Total RNA was quantified by absorption of light at 230, 260, and $280 \mathrm{~nm}$ (A230/260, A260/280) using a spectrophotometer (Ultrospec 2100 pro, Amersham Bioscience). To verify no genomic DNA contamination, we loaded total RNA in a $1 \%$ agarose gel that contained ethidium bromide $(\mathrm{EtBr})$ and visualized it on a UV transilluminator (Wealtec Corp., NV, USA). Subsequently, we loaded total RNAs in a $1 \%$ formaldehyde/ agarose gel with $\mathrm{EtBr}$ staining in order to verify the total RNA quality and verified the $18 / 28 \mathrm{~S}$ ribosomal RNAs integrity. After RNA quality was determined, single-stranded cDNA was synthesized from $2 \mu \mathrm{g}$ of total RNA of each sample using oligo $(\mathrm{dT})_{20}$ primer for reverse transcription in $20 \mu$ reactions (SuperScript ${ }^{\mathrm{TM}}$ III RT kit, Invitrogen, Carlsbad, CA).

\section{Real-time reverse transcriptase-polymerase chain reaction} (real-time RT-PCR)

Transcriptional levels of $T$. japonicus $A B C$ genes in each developmental stage were validated using real-time RT-PCR. Primers for each gene were designed after comparing the exon/intron boundary to genomic DNA using GENRUNNER software (Hastings Software, Inc. NY, USA) and were confirmed by the Primer 3 program (Whitehead Institute/MIT Center for Genome Research). To determine the amplicon identity, all the PCR products were cloned into the pCR2.1 TA vector and sequenced with an ABI 3700 DNA analyzer (Bionics Co., Seoul, South Korea). Optimized conditions were transferred according to the following CFX96 ${ }^{\mathrm{m}}$ real-time PCR protocol (Bio-Rad, Hercules, CA, USA). A no template control (NTC) reaction was included in every run for each primer pair in order to exclude DNA contamination in buffers/solutions and to assess primer dimers. Also, genomic DNA contamination was tested by the inclusion of controls that omitted the reverse transcriptase enzyme from the cDNA synthesis reaction (no RT controls). To set an appropriate reference gene for the real-time RT-PCR as a preliminary experiment, reliability of 9 reference candidates was validated using intra- and inter-laboratory validation procedures in a multiplex PCR condition (tubulin $\alpha$; glyceraldehyde 3-phosphate dehydrogenase, GAPDH; $\beta$-actin; DNAdirected RNA polymerase II subunit RPB2, POLR2B; glucose-6-phosphate dehydrogenase, G6PD; hypoxanthine phosphoribosyltransferase 1, HPRT1; TATA box binding protein, TBP; elongation factor $1 \alpha, \mathrm{EF} 1 \alpha ; 18 \mathrm{~S}$ ribosomal RNA, 18S rRNA) at different developmental stages of $T$. japonicus. As a result, the EF1 $\alpha$ gene showed the most stable expression pattern in all multiplex plates (data not shown). All real-time RT-PCR experiments were carried out in unskirted low 96-well clear plates (Bio-Rad,
Hercules, CA, USA). A total of $2 \mu \mathrm{g}$ of total RNA was used to synthesize cDNA for real-time RT-PCR. In each reaction, $0.2 \mu \mathrm{M}$ of each forward and reverse primer for each $A B C$ gene was employed (Table 1). Reaction conditions to detect specific PCR products were as follows: $94^{\circ} \mathrm{C} / 4 \mathrm{~min} ; 35$ cycles of $94^{\circ} \mathrm{C} / 30 \mathrm{sec}, 55^{\circ} \mathrm{C} / 30 \mathrm{sec}$, $72^{\circ} \mathrm{C} / 30 \mathrm{sec}$; and $72^{\circ} \mathrm{C} / 10 \mathrm{~min}$. SYBR ${ }^{\circ}$ Green (Molecular Probe Inc., Invitrogen). To confirm the amplification of specific products, cycles were continued to determine the melting curve under the following conditions: $95^{\circ} \mathrm{C} / 1 \mathrm{~min}$, $55^{\circ} \mathrm{C} / 1 \mathrm{~min}$, and 80 cycles of $55^{\circ} \mathrm{C} / 10 \mathrm{~s}$ with $0.5^{\circ} \mathrm{C}$ increase per cycle. All PCR products were sequenced at Bionics Co. (Seoul, South Korea). SYBR Green (Molecular Probes Inc., Invitrogen) was used to detect specific amplified products. Amplification and detection of SYBR Greenlabeled products were performed using the CFX96 realtime PCR system (Bio-Rad, Hercules, CA, USA). Data from triplicate experiments were expressed relative to expression of the internal control EF1 $\alpha$ gene that was used to normalize for any difference in reverse transcriptase efficiency. Each transcriptional level was determined by the

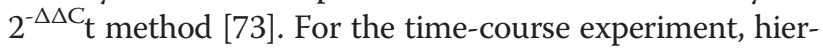
archical clustering analysis was employed in order to prepare a heat map using $\mathrm{MeV}$ v.7.4 software (Dana-Farber Cancer Institute, MA, USA).

\section{Additional files}

Additional file 1: Complementary DNA (CDNA) sequence for 46 full-length $A B C$ transcripts.

Additional file 2: Phylogenetic analysis of $T$. japonicus ABCA subfamily with those of other species using Bayesian method. Numbers at branch nodes represent the confidence level of posterior probability.

Additional file 3: Phylogenetic analysis of $T$. japonicus $A B C B$ subfamily with those of other species using Bayesian method. Numbers at branch nodes represent the confidence level of posterior probability.

Additional file 4: Phylogenetic analysis of $T$. japonicus ABCC subfamily with those of other species using Bayesian method. Numbers at branch nodes represent the confidence level of posterior probability.

Additional file 5: Phylogenetic analysis of $T$. japonicus ABCD and $A B C E$ subfamilies with those of other species using Bayesian method. Numbers at branch nodes represent the confidence level of posterior probability.

Additional file 6: Phylogenetic analysis of $T$. japonicus ABCF subfamilies with those of other species using Bayesian method. Numbers at branch nodes represent the confidence level of posterior probability.

Additional file 7: Phylogenetic analysis of $T$. japonicus ABCG subfamilies with those of other species using Bayesian method. Numbers at branch nodes represent the confidence level of posterior probability.

Additional file 8: Phylogenetic analysis of $T$. japonicus $\mathrm{ABCH}$ subfamilies with those of other species using Bayesian method. Numbers at branch nodes represent the confidence level of posterior probability. 
Additional file 9: Developmental stages of the intertidal hapacticoid copepod, $T$. japonicus. Stages 1-6 are nauplius (N) stages and five stages in the second row represent copepodite (C) stages. Figure was modified from our previous publication (Seo et al., 2006).

Additional file 10: Result of gene-specific hierarchical clustering analysis with temporal transcriptional expressions of $T$. japonicus 46 ABC transporters in different developmental stages ( $N$, nauplius; C, copepodid; M, male; F, female).

Additional file 11: Result of developmental stage-specific hierarchical clustering analysis with temporal transcriptional expressions of $T$. japonicus $46 \mathrm{ABC}$ transporters ( $\mathrm{N}$, nauplius; $\mathrm{C}$, copepodid; $\mathrm{M}$, male; $F$, female).

\section{Abbreviations}

ABC: ATP-binding cassette; CFTR: Cystic fibrosis transmembrane conductance regulator; ESTs: Expressed sequence tags; GSH: Glutathione; MDR: Multidrug resistance protein; MRP: Multidrug resistance-associated protein; NBD: Nucleotide binding domain; NR: Non-redundant; P-gp: P-glycoprotein; psu: Practical salinity units; SUR: Sulfonylurea receptor; TAP: Transporters associated with antigen processing; TBT: Tributyltin; TMD: Transmembrane domains.

\section{Competing interest}

The authors declare that they have no competing interests.

\section{Authors' contributions}

JSL and JSR designed the research study. CBJ and BMK analyzed the data. JSL and JSR wrote the manuscript with input from CBJ and BMK. All authors read and approved the final manuscript.

\section{Acknowledgements}

We thank three anonymous reviewers for their valuable comments on the previous manuscript. This work was supported by a grant of "Korea-Polar Ocean Development: K-POD" (project no. PM12030) funded by the Ministry of Land, Transport and Maritime Affairs, South Korea and also was supported by a grant of National Research Foundation (grant no. 2012R1A2A2A02012617).

\section{Author details}

${ }^{1}$ Department of Chemistry, College of Natural Sciences, Hanyang University, Seoul 133-791, South Korea. ${ }^{2}$ Department of Biological Sciences, College of Science, Sungkyunkwan University, Suwon 440-746, South Korea.

${ }^{3}$ Department of Marine Science, College of Natural Sciences, Incheon National University, Incheon 406-772, South Korea.

Received: 5 March 2014 Accepted: 31 July 2014

Published: 5 August 2014

\section{References}

1. Dean M, Rzhetsky A, Allikmets R: The human ATP-binding cassette (ABC) transporter superfamily. Genome Res 2001, 11:1156-1166.

2. Holland IB, Cole SPC, Kuchler K, Higgins CF: ABC proteins: from bacteria to man. Academic press: London Uk; 2003.

3. Davidson AL, Dassa E, Orelle C, Chen J: Structure, function, and evolution of bacterial ATP-binding cassette systems. Microbiol Mol Biol Rev 2008, 72:317-364.

4. Walker JE, Saraste M, Runswick MJ, Gay NJ: Distantly related sequences in the alpha- and beta-subunits of ATP synthase, myosin, kinases and other ATP-requiring enzymes and a common nucleotide binding fold. EMBO J 1982, 1:945-951

5. Moussatova A, Kandt C, O'Mara ML, Tieleman DP: ATP binding cassette transporters in Escherichia coli. Biochim Biophys Acta 2008, 1778:1757-1771.

6. Sheps JA, Ralph S, Zhao Z, Baille DL, Ling V: The ABC transporter gene family of Caenorhabditis elegans has implications for the evolutionary dynamics of multidrug resistance in eukaryotes. Genome Biol 2004, 5:R15.

7. Sturm A, Cunningham $P$, Dean M: The $A B C$ transporter gene family of Daphnia pulex. BMC Genomics 2009, 10:170.

8. Roth CW, Holm I, Graille M, Dehoux P, Rzhetsky A, Wincker P, Weissenbach J, Brey PT: Identification of the Anopheles gambiae ATP binding cassette transporter superfamily genes. Mol Cells 2003, 15:150-158.
9. Liu S, Zhou S, Tian L, Guo E, Luan Y, Zhang J, Li S: Genome-wide identification and characterization of ATP-binding cassette transporters in the silkworm, Bombyx mori. BMC Genomics 2011, 12:491.

10. Dermauw $W$, Van Leeuwen $T$ : The $A B C$ gene family in arthropods: Comparative genomics and role in insecticide transport and resistance. Insect Biochem Mol Biol 2013, 45:89-110.

11. Dermauw W, Osborne EJ, Clark RM, Grbić M, Tirry L, Van Leeuwen T: A burst of $A B C$ genes in the genome of the polyphagous spider mite Tetranychus urticae. BMC Genomics 2013, 14:317.

12. Broehan $\mathrm{G}$, Kroeger $\mathrm{T}$, Lorenzen $\mathrm{M}$, Merzendorfer $\mathrm{H}$ : Functional analysis of the ATP-binding cassette (ABC) transporter gene family of Tribolium castaneum. BMC Genomics 2013, 14:6.

13. Annilo T, Chen ZQ, Shulenin S, Costantino J, Thomas L, Lou H, Stefanov S, Dean M: Evolution of the vertebrate $A B C$ gene family: analysis of gene birth and death. Genomics 2006, 88:1-11.

14. Tyzack JK, Wang X, Belsham GJ, Proud CG: ABC50 interacts with eukaryotic initiation factor 2 and associates with the ribosome in an ATP-dependent manner. J Biol Chem 2000, 275:34131-34139.

15. Zhao Z, Fang $L L$, Johnsen $R$, Baillie DL: ATP-binding cassette protein $E$ is involved in gene transcription and translation in Caenorhabditis elegans. Biochem Biophys Res Commun 2004, 323:104-111.

16. Raisuddin S, Kwok KW, Leung KM, Schlenk D, Lee JS: The copepod Tigriopus: a promising marine model organism for ecotoxicology and environmental genomics. Aquat Toxicol 2007, 83:161-173.

17. Lee JS, Rhee JS, Kim RO, Hwang DS, Han J, Choi BS, Park GS, Kim IC, Park HG, Lee YM: The copepod Tigriopus japonicus genomic DNA information (574 Mb) and molecular anatomy. Mar Environ Res 2010, 69:S21-23.

18. Tribble ND, Burka JF, Kibenge FS: Evidence for changes in the transcription levels of two putative P-glycoprotein genes in sea lice (Lepeophtheirus salmonis) in response to emamectin benzoate exposure. Mol Biochem Parasitol 2007, 153:59-65.

19. Peelman F, Labeur C, Vanloo B, Roosbeek S, Devaud C, Duverger N, Denefle $P$, Rosier M, Vandekerckhove J, Rosseneu M: Characterization of the ABCA transporter subfamily: identification of prokaryotic and eukaryotic members, phylogeny and topology. J Mol Biol 2003, 325:259-274.

20. Decottignies $A$, Goffeau A: Complete inventory of the yeast $A B C$ proteins. Nat Genet 1997, 15:137-145.

21. Wenzel JJ, Piehler A, Kaminski WE: ABC A-subclass proteins: gatekeepers of cellular phospho- and sphingolipid transport. Front Biosci 2007, 12:3177-3193

22. Krishnamurthy PC, Du G, Fukuda Y, Sun D, Sampath J, Mercer KE, Wang J, Sosa-Pineda B, Murti KG, Schuetz JD: Identification of a mammalian mitochondrial porphyrin transporter. Nature 2006, 443:586-589.

23. Pondarré C, Antiochos BB, Campagna DR, Clarke SL, Greer EL, Deck KM, McDonald A, Han AP, Medlock A, Kutok JL, Anderson SA, Eisenstein RS, Fleming MD: The mitochondrial ATP-binding cassette transporter Abcb7 is essential in mice and participates in cytosolic iron-sulfur cluster biogenesis. Hum Mol Genet 2006, 15:953-964.

24. Ichikawa Y, Bayeva M, Ghanefar M, Potini V, Sun L, Mutharasan RK, Wu R, Khechaduri A, Jairaj Naik T, Ardehali H: Disruption of ATP-binding cassette $B 8$ in mice leads to cardiomyopathy through a decrease in mitochondrial iron export. Proc Natl Acad Sci U S A 2012, 109:4152-4157.

25. Liesa M, Qiu W, Shirihai OS: Mitochondrial $A B C$ transporters function: the role of $A B C B 10$ ( $A B C-m e)$ as a novel player in cellular handling of reactive oxygen species. Biochim Biophys Acta 1823, 2012:1945-1957.

26. Sooksa-Nguan T, Yakubov B, Kozlovskyy VI, Barkume CM, Howe KJ, Thannhauser TW, Rutzke MA, Hart JJ, Kochian LV, Rea PA, Vatamaniuk OK: Drosophila ABC transporter, DmHMT-1, confers tolerance to cadmium: DmHMT-1 and its yeast homolog, SPHMT-1, are not essential for vacuolar phytochelatin sequestration. J Biol Chem 2009, 284:354-362.

27. Sheppard DN, Welsh MJ: Structure and function of the CFTR chloride channel. Physiol Rev 1999, 79:S23-S45

28. Moreau C, Prost AL, Derand R, Vivaudou M: SUR, ABC proteins targeted by KATP channel openers. J Mol Cell Cardiol 2005, 38:951-963.

29. Russel FG, Koenderink JB, Masereeuw R: Multidrug resistance protein 4 (MRP4/ABCC4): a versatile efflux transporter for drugs and signaling molecules. Trends Pharmacol Sci 2008, 29:200-207.

30. Theodoulou FL, Holdsworth M, Baker A: Peroxisomal ABC transporters. FEBS Lett 2006, 580:1139-1155

31. Morita M, Imanaka T: Peroxisomal ABC transporters: structure, function and role in disease. Biochim Biophys Acta 1822, 2012:1387-1396. 
32. Sargent JR, Falk-Petersen S: The lipid biochemistry of calanoid copepods. Hydrobiologia 1988, 167/168:101-114.

33. Visser A, Jónasdóttir S: Lipids, buoyancy and the seasonal vertical migration of Calanus finmarchicus. Fish Oceanogr 1999, 8:100-106.

34. Teerawanichpan P, Qiu X: Molecular and functional analysis of three fatty acyl-CoA reductases with distinct substrate specificities in copepod Calanus finmarchicus. Mar Biotechnol 2012, 14:227-236.

35. Zhou A, Hassel BA, Silverman RH: Expression cloning of 2-5A dependent RNAase: a uniquely regulated mediator of interferon action. Cell 1993, 72:753-765.

36. Tian $Y$, Han $X$, Tian DL: The biological regulation of ABCE1. IUBMB Life 2012, 64:795-800

37. Barthelme D, Scheele U, Dinkelaker S, Janoschka A, Macmillan F, Albers SV, Driessen AJ, Stagni MS, Bill E, Meyer-Klaucke W, Schünemann V, Tampé R: Structural organization of essential iron-sulfur clusters in the evolutionarily highly conserved ATP-binding cassette protein ABCE1. J Biol Chem 2007, 282:14598-14607.

38. Meyer J: Iron-sulfur protein folds, iron-sulfur chemistry, and evolution. J Biol Inorg Chem 2008, 13:157-170.

39. Rouault TA: Biogenesis of iron-sulfur clusters in mammalian cells: new insights and relevance to human disease. Dis Model Mech 2012, 5:155-164.

40. Kerr ID: Sequence analysis of twin ATP binding cassette proteins involved in translational control, antibiotic resistance, and ribonuclease $L$ inhibition Biochem Biophys Res Commun 2004, 315:166-173.

41. Kovalchuk A, Driessen AJ: Phylogenetic analysis of fungal $A B C$ transporters. BMC Genomics 2010, 11:177.

42. Verrier PJ, Bird D, Burla B, Dassa E, Forestier C, Geisler M, Klein M, Kolukisaoglu U, Lee Y, Martinoia E, Murphy A, Rea PA, Samuels L, Schulz B, Spalding EJ, Yazaki K, Theodoulou FL: Plant ABC proteins - a unified nomenclature and updated inventory. Trends Plant Sci 2008, 13:151-159.

43. Sullivan DT, Grillo SL, Kitos RJ: Subcellular localization of the first three enzymes of the ommochrome synthetic pathway in Drosophila melanogaster. J Exp Zool 1974, 188:225-233

44. Mackenzie SM, Brooker MR, Gill TR, Cox GB, Howells AJ, Ewart GD: Mutations in the white gene of Drosophila melanogaster affecting $A B C$ transporters that determine eye colouration. Biochim Biophys Acta 1999, 1419:173-185

45. Kômoto N, Quan GX, Sezutsu H, Tamura T: A single-base deletion in an $A B C$ transporter gene causes white eyes, white eggs, and translucent larval skin in the silkworm $w-3^{\text {oe }}$ mutant. Insect Biochem Mol Biol 2009, 39:152-156

46. Kuwana H, Shimizu-Nishikawa K, Iwahana H, Yamamoto D: Molecular cloning and characterization of the $\mathrm{ABC}$ transporter expressed in Trachea (ATET) gene from Drosophila melanogaster. Biochim Biophys Acta 1996, 1309:47-52.

47. Baldán A, Tarr P, Lee R, Edwards PA: ATP-binding cassette transporter G1 and lipid homeostasis. Curr Opin Lipidol 2006, 17:227-232.

48. Tarling EJ: Expanding roles of ABCG1 and sterol transport. Curr Opin Lipidol 2013, 24:138-146.

49. Lamping E, Baret PV, Holmes AR, Monk BC, Goffeau A, Cannon RD: Fungal PDR transporters: phylogeny, topology, motifs and function. Fungal Genet Biol 2010, 47:127-142.

50. Kingtong $S$, Chitramvong $Y$, Janvilisri T: ATP-binding cassette multidrug transporters in Indian-rock oyster Saccostrea forskali and their role in the export of an environmental organic pollutant tributyltin. Aquat Toxicol 2007, 85:124-132.

51. Zhou J, He WY, Wang WN, Yang CW, Wang L, Xin Y, Wu J, Cai DX, Liu Y, Wang AL: Molecular cloning and characterization of an ATP-binding cassette $(A B C)$ transmembrane transporter from the white shrimp Litopenaeus vannamei. Comp Biochem Physiol C 2009, 150:450-458.

52. Hock T, Cottrill T, Keegan J, Garza D: The E23 early gene of Drosophila encodes an ecdysone-inducible ATP-binding cassette transporter capable of repressing ecdysone-mediated gene activation. Proc Natl Acad Sci U S A 2000, 97:9519-9524.

53. Gilbert LI, Rybczynski R, Warren JT: Control and biochemical nature of the ecdysteroidogenic pathway. Annu Rev Entomol 2002, 47:883-916.

54. Hwang DS, Lee JS, Lee KW, Rhee JS, Han J, Lee J, Park GS, Lee YM, Lee JS: Cloning and expression of ecdysone receptor $(E C R)$ from the intertidal copepod, Tigriopus japonicus. Comp Biochem Physiol C 2010, 151:303-312.

55. Dean M, Annilo T: Evolution of the ATP-binding cassette (ABC) transporter superfamily in vertebrates. Annu Rev Genomics Hum Genet 2005, 6:123-142.
56. Popovic M, Zaja R, Loncar J, Smital T: A novel ABC transporter: the first insight into zebrafish (Danio rerio) ABCH1. Mar Environ Res 2010, 69:S11-S13.

57. Liu S, Li Q, Liu Z: Genome-wide identification, characterization and phylogenetic analysis of 50 catfish ATP-binding cassette $(A B C)$ transporter genes. PLoS One 2013, 8:e63895.

58. Paffenhöfer GA: Grazing and ingestion rates of nauplii, copepodits and adults of the marine planktonic copepod Calanus helgolandicus. Mar Biol 1971, 11:286-298.

59. Berggreen $U$, Hansen $B$, Kiørboe T: Food size spectra, ingestion and growth of the copepod Acartia tonsa during development: implications for determination of copepod production. Mar Biol 1988, 99:341-352.

60. Lee HW, Ban S, Ikeda T, Matsuishi T: Effect of temperature on development, growth, and reproduction in the marine copepod Pseudocalanus newmani at satiating food conditions. J Plankton Res 2003, 25:261-271.

61. Andersen $\mathrm{H}$, Wollenberger $\mathrm{L}$, Halling-Soerensen B, Kusk K: Development of copepod nauplii to copepodites - a parameter for chronic toxicity including endocrine disruption. Environ Toxicol Chem 2001, 20:2821-2829.

62. Marcial HS, Hagiwara A, Snell TW: Estrogenic compounds affect development of harpacticoid copepod Tigriopus japonicus. Environ Toxicol Chem 2003, 22:3025-3030

63. LeBlanc GA: Crustacean endocrine toxicology, a review. Ecotoxicology 2007, 16:61-81.

64. Zhang S, Feany MB, Saraswati S, Littleton JT, Perrimon N: Inactivation of Drosophila Huntingtin affects long-term adult functioning and the pathogenesis of a Huntington's disease model. Dis Model Mech 2009, 2:247-266.

65. Bresciani J: The fine structure of the integument of free-living and parasitic copepods, a review. Acta Zool 1986, 67:125-145.

66. Tarnay JN, Szeri F, lliás A, Annilo T, Sung C, Le Saux O, Váradi A, Dean M, Boyd CD, Robinow S: The dMRP/CG6214 gene of Drosophila is evolutionarily and functionally related to the human multidrug resistance-associated protein family. Insect Mol Biol 2004, 13:539-548.

67. Luckenbach T, Epel D: ABCB- and ABCC-type transporters confer multixenobiotic resistance and form an environment-tissue barrier in bivalve gills. Am J Physiol Regul Integr Comp Physiol 2008, 294:1919-1929.

68. Leader JP, O'Donnell MJ: Transepithelial transport of fluorescent p-glycoprotein and MRP2 substrates by insect Malpighian tubules: confocal microscopic analysis of secreted fluid droplets. J Exp Biol 2005, 208:4363-4376.

69. Roepke TA, Hamdoun AM, Cherr GN: Increase in multidrug transport activity is associated with oocyte maturation in sea stars. Dev Growth Differ 2006, 48:559-573.

70. Hamdoun AM, Cherr GN, Roepke TA, Epel D: Activation of multidrug efflux transporter activity at fertilization in sea urchin embryos (Strongylocentrotus purpuratus). Dev Biol 2004, 276:452-462.

71. Kattner G, Krause M: Changes in lipids during the development of Calanus finmarchicus s.l. from copepodid I to adult. Mar Biol 1987, 96:511-518.

72. Andersen DS, Leevers SJ: The essential Drosophila ATP-binding cassette domain protein, pixie, binds the $40 \mathrm{~S}$ ribosome in an ATP-dependent manner and is required for translation initiation. J Biol Chem 2007, 282:14752-14760.

73. Livak KJ, Schmittgen TD: Analysis of relative gene expression data using real time quantitative PCR and the $2^{-\Delta \Delta C}$ tmethod. Methods 2001, 25:402-408

doi:10.1186/1471-2164-15-651

Cite this article as: Jeong et al:: Genome-wide identification of whole ATP-binding cassette (ABC) transporters in the intertidal copepod Tigriopus japonicus. BMC Genomics 2014 15:651. 